\author{
Michał Marcin KOBIERECKI \\ University of Lodz, Poland
}

\title{
American-Soviet Track and Field Exchanges as a Tool of Shaping Bilateral Political Relations ${ }^{*}$
}

\author{
Amerykańsko-radzieckie kontakty lekkoatletyczne \\ jako narzędzie kształtowania politycznych stosunków dwustronnych
}

\section{- Abstrakt •}

Celem badania jest analiza towarzyskich wymian lekkoatletycznych, do jakich dochodziło pomiędzy Związkiem Radzieckim a Stanami Zjednoczonymi w okresie zimnej wojny, z perspektywy ich roli w kształtowaniu stosunków pomiędzy państwami. Szczególna uwaga poświęcona została motywacji poszczególnych stron związanych z nawiązaniem kontaktów sportowych. Podjęto próbę przetestowania hipotezy, zgodnie z którą wymiany stanowiły wyraz chęci zbliżenia między państwami, a zarazem uzyskania korzyści propagandowych.

Słowa kluczowe: dyplomacja sportowa, Stany Zjednoczone, Związek Radziecki, sport i polityka, wymiany sportowe

\section{- Abstract •}

The aim of the research is to investigate the track and field exchanges between the United States and the Soviet Union in the Cold War era, in search of their role in shaping bilateral relations between the two states. Particular attention has been paid to the motivation of respective subjects. The research allowed to test the hypothesis stating that the track and field exchanges were an attempt to bring the two countries closer and to achieve propaganda benefits simultaneously.

Keywords: sports diplomacy, United States, Soviet Union, sport and politics, sports exchange

* The research has been financed by National Science Centre, Poland, within project number 2015/19/D/HS5/00513. 


\section{Introduction}

Cold War is a period associated most of all with ideological confrontation between two geopolitical blocks of states. The United States and the Soviet Union, and to some extent their allies, competed in various fields, including the space race, the arms race and struggle for influence in the non-aligned countries. Such rivalry included sport as well, which was used as a tool of gaining international prestige. Nevertheless, the Cold War was not only about confrontation between the superpowers. On some occasions their leaders also tried to establish various forms of cooperation. This was typical for the periods of détente, although not exclusively. The subject of the research conducted in the article is one of the examples of such attempts to cooperate between the United States and the Soviet Union - through friendly sports exchange in track and field.

Utilization of sport for the sake of shaping political relations between states is often named sports diplomacy, although the term itself may be understood in various ways. It may refer to the use of sport as a mean of political rapprochement between usually hostile states, as in the case of this research. Sports diplomacy may also mean transferring political conflicts to sport. Sports diplomacy can also be understood as mean of shaping international image of a country, and as an effect of diplomatic engagement of sports actors such as international sports governing bodies. Most often the term is regarded as one of the dimensions of public diplomacy.

The research presented in the article is an empirical case study concerning the use of sports exchanges in order to shape political bilateral relations between states, as the example of American-Soviet track and field dual meets. The data was acquired with the use of existing elaborations concerning cultural and sports exchange between the United States and the Soviet Union. Most of the used publications were historical. Within the investigation and attempt to answer a research question concerning the motivation of respective actors concerning establishing and continuing the sports exchanges was made. According to the main hypothesis to be tested in the article, the track and field USA-USSR exchanges were an expression of the desire to bring the societies of the two hostile countries closer, but at the same time to use them in order to achieve propaganda objectives about superiority of respective superpowers, even though those two goals may appear contradictory. 


\section{Establishing Cultural Exchanges}

Although the United States of America and the Soviet Union could definitely be described as hostile during the Cold War era, they never broke diplomatic relations and were keeping their embassies in the respective capital cities. There was also a whole range of diplomatic channels of dialogue, such as in the Security Council of the United Nations. If there was a political will for rapprochement despite ideological differences, leaders of both countries would not have had any difficulties in establishing contact. Contrary to for example Ping Pong diplomacy between the USA and communist China or USA-Cuba athletic relations, in this case sport was not necessary for this sake. Eventual sports exchange would simply be an extension of political relations.

A desire to establish a form of sports exchange could be observed on both sides since the beginning of the 1950s. It was not that easy though and required years of cautious negotiations. The first talks were held already in 1952 after the Olympic Summer Games in Helsinki (Turrini, 2001), which at the same time were the Olympic debut of the Soviet Union. The issue was also discussed by American president Dwight Eisenhower and Soviet Prime Minister Nikolai Bulganin during their meeting in Geneva in 1955. The two politicians were reported to have agreed upon a number of cultural exchanges, including a series of annual track and field meetings (Davies, 2007). As it can be observed, there was a mutual political will for a cultural cooperation, including sport, already in the first half of 1950s. Unfortunately there was a number of obstacles of establishing such contacts that had to be overcome. Probably it was simply too early considering the escalating hostility between the two nations in the immediate post-war period.

Considering the proposed track and field exchanges, Americans were proposing competitions between individual athletes without team scoring. On the other hand, the Soviet officials were standing on the position that that the meets should include competition of national teams. There was also a difference of opinions concerning the financing of the exchanges. However, the most important obstacle that was making the establishment of sports exchange impossible was different and had a legal background. Immigration and Nationality Act, also known as the McCarran Act was in force in the United States. It was a law passed in the USA at the beginning of the Cold War, at the time of anti-communist hysteria in this country. According to it, all citizens of the Soviet Union and other communist countries that were arriving in the United States had to have their fingerprints taken. However, the Soviet officials were disagreeing to this being done to their athletes visiting the United States. American Congress lifted this law in 1957, thus 
making the establishment of cultural and educational exchanges possible. This was the result of the fact that at the time many institutions in the USA including the administration of Dwight Eisenhower were insisting that sports exchanges with the USSR should be established. It was meant to be a useful tool of communication with the people of the Soviet Union, and sending message of the success of American democracy and capitalism (Turrini, 2001). Such intention suggests that the "track and field diplomacy" between the United States and the Soviet Union was not directed at political rapprochement exclusively, but also at promoting particular interests of respective countries, the USA in this case, within the ideological conflict.

While analysing the circumstances of establishing bilateral sports exchanges between the USA and the USSR, one should not omit the internal changes that the Soviet Union was undergoing at the time. According to Yale Richmond (2003), establishment of cultural cooperation and contacts with the West was only possible after the changes initiated by the $20^{\text {th }}$ Congress of the Communist Party of the Soviet Union in 1956, when Nikita Khrushchev signalized a shift in the Soviet policy. He spoke about peaceful coexistence and increase of contacts with the West. In reference to this, the Soviet Union has signed a number of cultural agreements with the Western countries, for example with Belgium and Norway in 1956, and with France and Great Britain in the following year. In October 1957 formal negotiations between the United States and the Soviet Union have been initiated, which resulted in signature of an agreement on 27 January 1958. Popularly it is referred to as Cultural Agreement. The document credited cooperation and exchanges in many fields, including science and technology, agriculture, radio, television, youth, sport, medicine, public health, culture and tourism. For example an exchange of television programmes was decided, although their scripts were to be approved by respective governments. Direct air connection was to be started and exchanges at the level of members of parliaments were to be established. The agreement was signed for two years, but within the following 30 years it was renewed many times. The establishment of such cooperation was described as a "historical cultural accord between the USA and the USSR" (Belmonte, 2008), and both sides immediately began to execute its provisions (Molander, 1991).

The sports dimension of the cultural exchange between the Unites States and the Soviet Union is obviously the most important, but it should be noted that a number of forms of cooperation between the two countries were established at the time. For example the International Tchaikovsky Competition in classical music in 1958 was won by an American pianist Van Cliburn. Some claimed that the Soviet Union did not register its best pianist Vladimir Ashkenazy and that the 
musical repertoire of the competition was favouring the American contestant. All this was believed to be intentional, in order to show Cliburn to the Soviet Society as a people's hero, therefore stressing the new approach of peaceful coexistence (Cosentino, 2006). Although it was not a sports event and is not a direct subject of the research, it Soviet motivation is worth to be noted. Apparently Soviet leadership wanted to convince the society of the USSR that it should change its attitude to the United States, a country that the Soviet propaganda was describing in the past as the ultimate enemy. Obviously the idea of peaceful coexistence initiated by Khrushchev required appropriate social engineering. Apparently such a nonpolitical field as culture and sport appeared to be a perfect tool for achieving such objective.

\section{Beginning of Track and Field Exchanges}

According to the American-Soviet cultural agreement, which is also referred to as Lacy-Zaroubin Agreement from the names of the main negotiators - the Soviet ambassador Georgi Zaroubin and the American ambassador S. B. Lacy (Maraniss, 2008), two track and field meets were to be organized. The first one was to be held in Moscow in 1958, while the other one in the United States in the following year. Actually there were a lot more sports exchanges established on the basis of the Cultural Agreement. They included sports friendly meets in basketball, weightlifting and wrestling (Turrini, 2001). It is worth noting that the first such contacts were held even before the signature of the Lacy-Zaroubin Agreement, as in June 1955 weightlifters from the United States visited Moscow and Leningrad. However, it was since 1958 that Soviet-American friendly sports contacts flourished. Already in 1958 weightlifters from the Soviet Union visited the United States and performed in Chicago, Detroit and New York. America was also visited by Soviet wrestlers, while American basketball players have come to play in the Soviet Union (Rosenberg, 2005; Pasko, 2012). The number of sports exchanges between the two countries was significant bearing in mind the mutual attitude of both countries until then. However, the exchanges in track and field have gained the greatest interest and political significance.

The organization of the first track and field meet in Moscow was negotiated by privately financed Amateur Athletic Union (AAU) from the American side, while from the Soviet side by the All-Union Physical Culture Council, which was an agency with the status of a ministry. The formula of the competition was rather simple. There were 22 men and 10 women competitions to be held. Two 
participants from each country were to participate in every competition and they were receiving points according to their final rank: five points of the first place, three points for the second place, two points for the third place and one point for the fourth place. In relays, one team was supposed to represent each country. The winning team of the relay was receiving five points, while the losing team - three points. The whole formula was a subject of debate before the events, as Americans were opting for two separate competitions for men and women (Elzey, 2010; Turrini, 2001). As a matter of fact, communist countries including the Soviet Union were using the circumstance that ladies' sport in the West was regarded as less important and strongly underfunded at the time. Soviet sports officials saw it as $s$ niche that could be used in order to achieve international prestige through sports competition (McComb, 2004). It was one of the reasons for Soviet dominance in the Olympic Games at the time. As a result of that, the Americans assumed that they might have won the track and field meet's men competition, at the same time being prepared to lose decisively in the ladies' competition. The Soviet Union on the other hand was interested in calculating the results of men and women together, hoping that their advantage in ladies' competition would make them win in the overall ranking. This was revealing new motivation of both sides, different from the earlier mentioned desire to promote closer relations. Apart from this, both sides were strongly interested in winning the meets, perceiving it from the perspective of international prestige.

Shortly before the American team was to set off for the meet in Moscow, political tension appeared. Nikita Khrushchev in his response to the situation in the Middle East asked for organization of a political summit with the United States and three other countries, but Dwight Eisenhower did not agree. American Amateur Athletic Union's officials were fearing that this might lead to a cancellation of the exchange by the Washington, but it did not happen. It was believed in the US Department of State, that if any anti-American protests would be held in Moscow, they would put the Soviet Union in a bad light. As a result the meet was not cancelled and a delegation of 72 American athletes, coaches and officials set out for Moscow, while three other athletes joined the team in Helsinki as they were competing in Europe at the time (Elzey, 2010).

The first of the series of American-Soviet track and field dual meets was held in Moscow in July 1958. The event took two days. It was important from the sports diplomacy perspective, that friendly character of the exchange was exposed very heavily. Soviet newspaper Pravda described the meet as a part of the principle of peaceful coexistence. As for the fans, they were particularly interested in competition between decathletes Vasily Kuznetsov and Rafer Johnson. The latter 
man bet a world record during the meet -8302 points. In the future both athletes were breaking the world record alternately a few more times (Porter, 1995). 75.000 people were cheering for both of them, while the athletes embraced each other after the competition as a gesture of mutual respect and friendship (Davies, 2007; Rosenberg, 2005). Soviet newspaper Trud was praising Americans for their long-lasting dominance in international sport (Elzey, 2010). Such hospitability of the Soviets is a typical thing for such sports diplomacy. It is meant to emphasize positive emotions between the countries participating in the exchange. Bearing in mind the Soviet leaders controlled the media in the country, such releases can be regarded to some extent as unofficial statements of the state's decision-makers. Therefore it may be assumed that the exchange was meant to shape a more favourable attitude towards the United States among the Soviet society, so that it would comply with the new political line.

The track and field dual meet between the Soviet Union and the United States in Moscow in 1958 was assessed by the Soviet press as "the match of the century". It was believed to be an important moment concerning the American-Soviet relations, as for the first time the two Cold War superpowers arranged a sports exchange in a sport that was important to both of them. The fact that track and field was very popular both in the United States and in the Soviet Union was to guarantee that both societies would be interested in such exchange - a "clash of sporting titans in which neither side held an inherent advantage" (Elzey, 2010). When sports diplomacy is considered, a choice of a proper sport for the exchange is often referred as an important factor of its effectiveness. In this case a sport that was regarded as important in both societies was selected. This led to a situation that both the United States and the Soviet Union were interested in winning in such a prestigious contest. A question may appear then, whether this was not diminishing the positive diplomatic objectives that were associated with the exchange. It appears that the answer is no, as bearing in mind the diplomatic intentions only a popular sport may have been effective. Of course the situation would be different if nationalist atmosphere was present - in the media, in the behaviour of athletes or the fans. It did not happen though.

Americans sent a very strong team to the track and field dual meet in Moscow, including Olympic gold medallist and eight world record holders. Soviet officials also wanted to have as good team as possible, for example by enhancing selection system. In the Soviet team there were Olympic medallists as well, but in general it was expected to lose against the USA. However, in the end the Soviet team was slightly better, winning 172-170 in points. It was described as the first defeat of the American team for decades. On the other hand, for Americans the male com- 
petition was the most important and this category was won by the United States. As a result, American media were claiming that the Team USA won the event. Such situation was typical also for the USA-USSR track and field exchanges in the future, when both sides were perceiving themselves as winners (Elzey, 2010). It was similar if the Olympic Games are considered - when it was possible both countries, particularly the Soviet Union, were trying to manipulate the results in order to declare itself as the best sports nation in the world.

\section{Continuation of Track and Field Exchanges}

As has been arranged, the second American-Soviet dual meet was supposed to held in the USA in the following year. It was organized in Philadelphia between 18 and 19 June 1959 (Tricard, 1985). According to William J. Baker (1988), the meet helped pave way for a visit of Nikita Khrushchev in the United States. The visit took place in September 1959 and was reported to be held in a friendly atmosphere, although America did not impress the Soviet leader as strongly as it was expected. The meeting of the heads of two Cold War superpowers resulted in declarations of a will to reach amicable settlement of the Berlin problem related to Soviet ultimatum about withdrawal of the Western powers from the city, which was meant to be demilitarised (Dunbabin, 2008). Baker's view that the track and field meeting in 1959 helped in organizing Khrushchev's visit is cited by many researchers, however it appears that the connection between the sports exchange and the meeting of political leaders was not as direct as in case of for example Richard Nixon's visit to China. The possible contribution of the dual meet in Philadelphia was probably more indirect and encompassed most of all shaping slightly better image of the Soviet Union among the American society. This was very similar to the Soviet objective of the exchanges during the meet in Moscow in the preceding year.

The American-Soviet track and field dual meets were organized alternately in both countries in the following years as well. The visit of Soviet athletes to Stanford in July 1962 is believed to be one of the most attention-grabbing, as it was held shortly after the Cuba missile crisis. The event was watched by 81.000 viewers live, while 153.000 tickets for this lasting two days event were sold altogether (Cavali, 2005, Turrini, 2001). It was the peak of popularity of this annual bilateral sports event, also described as the "the most important track meet in the world outside the Olympic Games" (Turrini, 2010). What is more, as a result a low number of participants representing only two nations, the events was very strongly reflect- 
ing the Cold War perspective, thus evoking patriotic feelings among athletes and coaches. For example, an already mentioned American athlete Rafer Johnson described the competition from 1958 as "communism versus the free world" (Turrini, 2001). The great interest the meets were raising was also the result of the sport that has been chosen for the exchange. Track and field was important and popular both in the United States and in the Soviet Union. Therefore a political dimension of the sports exchange could be visible not only in the aspect of shaping sympathy between respective societies, but also through attempts to communicate superiority of one political and economic system over another.

The series of annual track and field USA-Soviet exchanges was held continuingly until 1966, despite many political problems that were arousing in the meantime. Both Berlin crisis and Cuban missile crises did not lead to a cancellation of any of the friendly events. As Victor Rosenberg (2005) stated, sport was at the time one of the exclusive areas of exchange that did not suffer from growing political tensions, thus proving how important they were for both Cold War superpowers. Finally though, political issues resulted in interrupting the exchanges. Soviet Union decided to respond to the American engagement in the Vietnamese War and a general deterioration of bilateral relations at the time. As a result, Soviet leaders decided to withdraw from the track and field meet that was scheduled for summer 1966 in Los Angeles. Americans were informed about the boycott two weeks before the event was scheduled. Officially the Soviet side explained the decision as a spontaneous demonstration of Soviet athletes against the American policy (Cosentino, 2006; Pasko, 2012; Turrini, 2001). Such official explanation, as the athletes' choice, suggested a grassroots character of the outcome, thus implying moral purposes. Bearing in mind how the Soviet Union used to pursue its sports policy, it is highly improbable that it were the athletes to suggest the boycott.

The cancellation of the meet planned to be held in the United States made it difficult to resume the track and field exchanges in the future, and possibly even the whole cultural exchange programme. American media were even claiming that the Soviets only used the war issue in order to save their face as the country's athletes were representing lower level than the US team. One of the American journalists even claimed, that the Soviets never risked competing in sport if they were not pretty sure they would win. Such reasons appear to be highly improbable though as Soviet female athletes have won seven consecutive dual meets before, while in the preceding year the USSR for the first time won the male competition as well (Turrini, 2001). Those views that were raised in the United States can be assessed as a desire to politically utilize sports victories for the sake of national prestige, which was typical for the Cold War East-West relations. Even when com- 
petitions between the two superpowers were cancelled because of, for example, boycotts, both sides were looking for an opportunity to stress their excellence and weakness of the other side. This issue also confirms the earlier assumption that track and field diplomacy between the United States and the Soviet Union, apart from the most obvious objective of political rapprochement, were also aimed to be used within the typical Cold War rivalry.

The first phase of the series of USA-USSR track and field exchanges that was ended in 1966 was assessed not only as a political success, but also as a commercial success, at least in the capitalist United States. As a matter of fact, the Amateur Athletic Union was gaining many benefits from the exchange, which was resulting from its great popularity. This convinced the AAU to begin organizing track and field dual meets also against other countries. This included overseas meets in Poland in 1958, 1961, 1963 and 1965, in Greece in 1958, in Hungary in 1958, in West Germany in 1961, 1963 and 1965, in Great Britain in 1863 and 1965. The home track and field meets were held for example against Poland in 1962 in Chicago and in 1965 in Los Angeles, and against West Germany in 1965 in Los Angeles. However, they all grabbed far less attention than the meets against the Soviet Union (Turrini, 2001; Turrini, 2010). Regardless the commercial objectives, those meets also had a diplomatic meaning concerning political rapprochement, particularly against communist countries such as Poland and Hungary. They were far less important from the diplomatic perspective than the meets with the USSR though.

In its pursuit of profit AAU made American athletes less interested in participating in the track and field exchanges against the Soviet Union. As a result, one of the exchanges from the first phase of the annual dual meets in 1961 was boycotted by them. Nine American athletes including hammer thrower Hal Connolly decided not participate in the event. They constituted one fourth of the whole US male team. The boycott did not have any political meaning. It was simply an expression of disagreement against the difficulties that the overseas competitions organized by the Amateur Athletic Union were causing. The foreign trip in that year included competitions in Poland, Great Britain, West Germany and the Soviet Union. The athletes claimed that it was taking too long and collided with their professional and family life. Therefore they wanted to compete only against the Soviet Union, but the AAU did not agree to this. The whole issue raised a lot of controversies in the United States. For example senators Claire Engle and J. William Fulbright protested that if Department of State supported financially AAU in its trip to Moscow, it should remain some control over the quality of the national team. As Engle stated, "we all know that Russians use the athletic events 
for propaganda purposes... We may be supplying them with another opportunity of claiming superiority over the United States" (Turrini, 2010).

With the passing time American athletes appeared to be losing interest in participating in the dual meets against the Soviet Union. What is more, internal conflicts began to happen within the American sport. Amateur Athletic Union was challenged by another sports organization United States Track and Field Federation (USTFF) which was searching for a way to enhance its profile. For example USTFF led a boycott of qualifications to the American team for the meeting against the Soviet Union in 1965. As a result a few of the best American athletes were not able to compete against the Soviets (Turrini, 2001). In this year American male team lost against the Soviet Union in the dual meet for the first time. The boycott possibly might have contributed to this result.

\section{Diminishing Role of Track and Field Exchange}

The Soviet boycott of the 1966 event was not the end of the track and field exchange between the two Cold War superpowers. It was simply the end of its first phase. The resumption of the series of meets was not easy though. As has been mentioned, once the annual meets gained great popularity, Amateur Athletic Union began to perceive the event as a source of revenue. Cancellation of an event to be held in the United States led to financial loss by the AAU. As a result, the Union demanded compensation from the Soviet Union and was ready to invite Soviet athletes to the United States only after it is paid. This obviously made it difficult to resume the exchange. However, with the passing time AAU appeared to be loosening its position. For example in 1968 a few Soviet athletes competed in the United States during the indoor season even though the USSR did not pay the compensation (Turrini, 2001). The existing exchanges were less formal though and did not include competitions of national teams.

The changing attitude of the Amateur Athletic Union allowed to begin the second phase of the American-Soviet track and field exchange in 1969. The formula of the competition was changed at the time. Indoor, junior and all-round events began to be organized apart from the previous form. The second phase lasted until 1985, but the significance of the meets was far smaller than of the ones in the first phase. It was the time of a growing professionalization of track and field. Competitions with the selected athletes that were oriented at world record breaking began to be organized. What is more, the international federation IAAF began its efforts to organize the world championships, which were held for the first time in 
1977. All this led to diminishing importance of the team competitions. The sport was changing and as a result some earlier forms of competition, including the dual meets, were not that attractive any more.

The changing face of international track and field resulted in significant deterioration of the level of bilateral exchanges between the Soviet Union and the United States. They did not gain the same political significance as in the time before the Soviet boycott. According to athletes, there were many occasions to compete against the Soviet Union, so the bilateral series lost its status of the second competition after the Olympic Games. The big number of track and field competitions was even making it difficult to arrange time of the dual meet. For example lack of agreement upon the time of the meet resulted in cancellation of the event in 1979. After that the meets were organized in 1981, 1982 and 1985, but the last one was in fact a competition of three countries. It was held in Japan, but the points of the American-Soviet competition were counted separately (Turrini, 2001; Turrini, 2010). All those circumstances led to a vast deterioration of the once prestigious track and field event. In the last years of the exchange their continuation was suspended repeatedly and in the end the whole concept was abandoned without any single reason.

\section{Conclusion}

The bilateral annual track and field events between the United States and the Soviet Union appear to be a pure example of positive sports diplomacy that was a tool of achieving particular objectives of states. Those goals included an attempt to bring the two Cold War superpowers closer despite their ideological conflict. Contrary to, for example, the Ping Pong diplomacy between the USA and the communist China, this exchange was not necessary to establish political and diplomatic relations. Their main goal, at least in the first phase, was to affect the respective societies - to make them more open towards the other country. This was very important concerning the alteration of their bilateral relations, once Nikita Khrushchev announced peaceful coexistence and the anti-communist hysteria in the United States passed. Therefore the image of the ultimate enemy of the USA in the Soviet Union and vice-versa had to be altered. Cultural exchanges, including the very popular track and field dual meets, were the tool to achieve it.

Even though both sides were interested in political rapprochement, at least to some extent, at the same time each of the competing nations wanted to dominate athletically in the events. This was visible from the very beginning when the for- 
mula of the events was negotiated and both the Soviets and the Americans were backing the solution that would give them the advantage. The dual meets were posing opportunities for exposing patriotic feelings, but at the same time were constituting a showcase for expressing friendly attitudes. Therefore a hypothesis stating that the American-Soviet track and field exchanges were an attempt to bring the two countries closer and to achieve propaganda benefits simultaneously appears to be highly probable, even though those two elements are contradictory.

It appears that the American-Soviet track and field exchange had positive effects, particularly during its first phase. Positive emotions were dominating during the meets even though various controversies, protests and accusations were happening and one of the goals of both sides was to athletically defeat the ideological rival. As one of Soviet long-jump athletes Igor Ter-Ovanesyan was reported to have said, "We found ourselves equally able to be ferocious on the running track and friendly in the everyday life" (Whiterspoon, 2014). Such atmosphere was taken up by media in their coverage, which on some occasions described goodwill and friendliness between the two sides, while at other times spoke about the desire to crash the rivals. Such activities that encompass attempts to use the relations between single people for the purpose of interstate relations are typical for public diplomacy - a category that includes sports diplomacy.

\section{References:}

Baker, W.J. (1988). Sports in the Western World. Urbana and Chicago: University of Illinois Press.

Belmonte, L.A. (2008). Selling the American Way. U.S. Propaganda and the Cold War. Philadelphia: University of Pennsylvania Press.

Cosentino, F. (2006). Hail Mary Heaven Sent. Eganville: Lulu Press.

Davies, R.O. (2007). Sport in American Life. A History. Malden: Blackwell Pub.

Dunbabin, J.P.D. (2008). The Cold War. Abingdon: Routledge.

Elzey, C. (2010). The Match of a Century. The U.S. - USSR Rivalry in Sports. In: D.K. Wiggins, R.P. Rodgers (eds.), Rivals. Legendary Matchups That Made Sports History (p. 327-358). Fayeteville: The University of Arkansas Press.

Molander, E.A. (1991). Bridge Building from Grass Roots: Organization and Management of Citizen Diplomacy Programmes. In: D. Leviton (ed.), Horrendous Death and Health. Toward Action (p. 227-244). New York: Hemisphere Publishing Corporation.

Maraniss, D. (2008). Rome 1960. New York: Simon \& Schuster.

McComb, D.G. (2004). Sports in World History. New York: Routledge.

Tricard, L.M. (1985). American Women's Track and Field. A History, 1895 through 1980. Jefferson: MacFarland \& Company. 
Pasko, A. (2012). Sport wyczynowy w polityce państwa 1944-1989. Kraków: Avalon.

Porter, D.L. (ed.). (1995). African-American Sports Greats. A Biographical Dictionary. Westport: Greenwood Publishing Group.

Richmond, Y. (2003). Cultural Exchange and the Cold War. Raising the Iron Curtain. University Park: Penn State University Press.

Rosenberg, V. (2005). Soviet-American Relations, 1953-1960. Diplomacy and Cultural Exchange During the Eisenhower Presidency. Jefferson: McFarland \& Company.

Turrini, J.M. (2001). "It Was Communism Versus the Free World": The USA USSR Dual Track Meet Series and the Development of Track and Field in the United States, 1958-1985. Journal of Sport History, Vol. 28, 3, 427-471.

Turrini, J.M. (2010). The End of Amateurism in American Track and Field. Champaign: University of Illinois Press.

Whiterspoon, K.B. (2014). „Fuzz Kids” and „Musclemen”: The US-Soviet Basketball Rivalry, 1958-1975. In: H.L. Dichter, A.L. Johns (eds.), Diplomatic Games. Sport, stagecraft, and International Relations Since 1945 (p. 297-326). Lexington: University Press of Kentucky. 